\title{
Gas exchange and nutrient content in leaves of physic nut irrigated with wastewater and doses of phosphorus
}

\section{Trocas gasosas e teor de nutrientes em folhas de pinhão manso irrigado com água residuária e doses de fósforo}

\author{
Antonio Evami Cavalcante Sousa ${ }^{1 *}$; Claudivan Feitosa de Lacerda ${ }^{2}$; \\ Hans Raj Gheyi ${ }^{3}$; Frederico Antonio Loureiro Soares ${ }^{4}$; \\ Elka Costa Santos Nascimento ${ }^{5}$; Ricardo Almeida Viégas ${ }^{6}$
}

\begin{abstract}
With the objective of evaluating leaf gas exchange and nutrient concentration in plants of physic nut irrigated with wastewater of domestic origin an experiment was conducted in protected ambient adopting randomized block in factorial layout, to study the effects of five levels of hydric reposition - HR ( 0.25 ; $0.50 ; 0.75 ; 1.00$ and 1.25 times of water consumed by the plant), and two levels of phosphorus (135 and $200 \mathrm{~g} \mathrm{P}_{2} \mathrm{O}_{5}$ plant $^{-1}$ year $^{-1}$ ) with four repetitions. The data of leaf gas exchange were obtained using a portable photosynthesis meter (IRGA). To determine the nutrient content of the plant, fourth and fifth leaves below the inflorescence was used. The reduction in water supply provoked reduction in the rate of carbon assimilation, limiting the production capacity of the physic nut plants. The increase in level of hydric reposition with wastewater resulted increase in leaf gas exchange, notably in the rate of carbon assimilation. The accumulation of the nutrient follows the sequence: $\mathrm{N}>\mathrm{K}>\mathrm{Ca}>\mathrm{Na}>\mathrm{Cl}>\mathrm{Mg}>\mathrm{P}>$ $\mathrm{S}>\mathrm{Fe}>\mathrm{Mn}>\mathrm{Zn}>\mathrm{Cu}$, and with the increase of water supply the leaf contents of phosphorus, zinc and copper increased. The doses of $\mathrm{P}_{2} \mathrm{O}_{5}$ did not influence the contents of studied elements.
\end{abstract}

Key words: Jatropha curcas L., mineral nutrition, photosynthetic characteristics, phosphate fertilizer, reuse

\section{Resumo}

Com o objetivo de avaliar trocas gasosas e teores de minerais em plantas de pinhão manso irrigadas com água residuária de origem doméstica foi conduzido um ensaio em ambiente protegido adotando-se um delineamento em blocos casualizados em um fatorial com cinco níveis de reposição hídrica $(0,25$; $0,50 ; 0,75 ; 1,00$ e 1,25 do consumo de água pela planta $)$ e duas doses de $\mathrm{P}_{2} \mathrm{O}_{5}\left(135\right.$ e $\left.200 \mathrm{~g} \mathrm{planta}^{-1}\right)$ por ano com quatro repetições. Os dados de trocas gasosas foliares foram obtidos utilizando-se medidor portátil de fotossíntese (IRGA). Para determinar o teor de nutrientes da planta, utilizou-se o limbo foliar localizado entre a quarta e quinta folha abaixo da inflorescência. A redução da reposição hídrica

\footnotetext{
${ }^{1}$ Doutorando em Engenharia Agrícola. Bolsista CNPq, Universidade Federal de Campina Grande, UAEA/UFCG, Campina Grande, PB. E-mail: evami@ibest.com.br

${ }^{2}$ Prof. Adjunto, Universidade Federal do Ceará, DENA/UFC, Fortaleza, CE. E-mail: cfeitosa@ufc.br

${ }^{3}$ Prof. Visitante Nacional Sênior, Universidade Federal do Recôncavo Baiano, NEAS/UFRB Cruz das Almas, BA. E-mail: hans@, pq.cnpq.br

${ }^{4}$ Prof. do Instituto Federal Goiano. IF Goiano, Campus Rio Verde, GO. E-mail: fredalsoares@hotmail.com

${ }^{5}$ Graduando em Engenharia Agrícola. Bolsista PIBIC/CNPq, Universidade Federal de Campina Grande, UAEA/UFCG, Campina Grande, PB. E-mail: elka costa@hotmail.com

${ }^{6}$ Prof. Adjunto, Universidade Federal de Campina Grande, UAEF/UFCG, Patos, PB. E-mail: raviegas@uol.com.br

* Author for corespondence
} 
provocou diminuição na taxa de assimilação de carbono, limitando a capacidade produtiva das plantas de pinhão manso. $\mathrm{O}$ incremento na reposição hídrica com água residuária proporcionou incremento nas trocas gasosas foliares, notadamente na taxa de assimilação de carbono. Verificou-se que o acúmulo dos elementos segue a sequência: $\mathrm{N}>\mathrm{K}>\mathrm{Ca}>\mathrm{Na}>\mathrm{Cl}>\mathrm{Mg}>\mathrm{P}>\mathrm{S}>\mathrm{Fe}>\mathrm{Mn}>\mathrm{Zn}>\mathrm{Cu}$, e com o aumento da reposição hídrica, o fósforo, o zinco e o cobre aumentaram suas concentrações no limbo foliar. As doses de $\mathrm{P}_{2} \mathrm{O}_{5}$ aplicadas não influenciaram os teores de nenhum dos elementos estudados.

Palavras-chave: Jatropha curcas L., nutrição vegetal, características fotossintéticas, adubação fosfatada, reúso

\section{Introduction}

In semi-arid areas, irrigation is responsible for consuming 50 to $85 \%$ of available water resources (CAPRA; SCICOLONE, 2007). To find more efficient irrigation methods and alternative water resources such as the use of wastewater to reduce competition for water is a worldwide trend. The reuse water for irrigation is a practice widely studied and recommended by many researchers as a viable alternative to meet water needs and, largely, nutritional of plants (CAPRA; SCICOLONE, 2007; HERPIN et al., 2007). Besides recovering the effluent, reduce environmental pollution and promote the formation of humus (WHO, 1989), water reuse can facilitate agricultural activity, as well as human sustainability in areas with poor survival (REBOUÇAS et al., 2010).

In general, the water collected from sewage contains a large extent, of the nutrients required for growth of plants, being the more interesting agronomically phosphorus, nitrogen, potassium, zinc, boron and sulfur, whose content, in these waters generally meets if not all, but at least a good part of the nutritional needs of plants (AZEVEDO et al., 2007). However, studies show that the phosphorus in sewage water collected often not meets the needs of plants and therefore requires a complement. On the other hand, any excess of this element in the irrigation water does not bring any harm to plants (BLUM, 2003). According to Johns and McConchie (1994), it has been observed in the literature, increase in the levels of this element in soils irrigated with effluent sewage, in agricultural systems, however these increases do not are excessive.
According to van der Hoek et al. (2002), the major advantages of the use of wastewater for agriculture consist of the conservation of water available and the possibility of recycling of nutrients (reducing the need for chemical fertilizers), contributing to the preservation of the environment. Ferreira, Beltrão and Koing (2005) found that the treated wastewater contributed to the increase of production and improves the quality of cotton fibers, probably due to the nutritional potential of the effluent. Other studies have also indicated the importance of the treated effluent for reuse as alternative, acting positively in the fertilization of various species such as chili (SOUSA et al., 2006), seedlings flamboyant (LUCENA et al., 2007), gerberas (MEDEIROS et al., 2007), sunflower (NOBRE et al., 2009, SOUZA et al., 2010) and bean cowpea (REBOUÇAS et al., 2010).

The recommendation of fertilization for crops depends on the nutritional demands of plants for the vegetative and reproductive growth (LAVIOLA et al., 2007). In this sense, both the chemical composition, and nutrient accumulation in leaves is information essential to meet the nutritional requirements of crops.

In the case of an agricultural species, it should be remembered that the vegetative behavior is highly dependent on climatic factors such as temperature, rainfall, soil moisture and solar radiation (LARCHER, 2004). The interaction between photosynthesis, growth and development of plants and seasonal climatic variations in a given region makes productivity yields highly dependent on these variations (LEMOS-FILHO, 2000). Among the physiological events most affected by 
environmental conditions this the photosynthesis, which has received special attention in studies aimed at the selection of species and/or varieties suited to harsh environments, being the primary source of organic carbon and energy for growth and biomass production of plants (DENG et al., 2003; SANTOS, 2008).

An alternative cultivation with water reuse is the oleaginous, because they are not consumed raw for its and bioenergetics importance, and government incentives to recommend some species for the production of biodiesel. Because of this interest, several studies have been conducted relating the physiological behavior of different species of plants like the castor oil, peanuts and physic nut, trying to understand, especially the photosynthetic capacity, stomatal conductance and water potential under controlled environmental conditions and under conditions naturals (NOGUEIRA; SANTOS, 2000; BELTRÃO et al., 2003; ERISMANN; MACHADO; GODOY, 2006; MACEDO et al., 2011). On the other hand, little is known about the physiology of physic nut, (Jatropha curcas L.). Studies with this oilseed justified in view of its high yield potential and for being identified as an important alternative for the supply of oil to produce biodiesel in Brazil, especially in the semiarid region (BELTRÃO, 2005; MACEDO et al., 2011).

Taking into consideration the use of fertilizers applied and the fraction of nutrients supplied by irrigation this study, the present work aimed to evaluate gas exchange and quantify the levels of nutrients in leaves of physic nut cultivated with different depth of hydric reposition using effluents from domestic and two levels of phosphorus.

\section{Material and Methods}

The study was conducted in a greenhouse belonging to the Academic Unit of Agricultural Engineering, Federal University of Campina Grande, in Campina Grande, Paraiba, Brazil with the following geographical coordinates: $07^{\circ} 15^{\prime} 18^{\prime \prime}$ South latitude, $35^{\circ} 52^{\prime} 28^{\prime \prime}$ of West longitude and altitude of $550 \mathrm{~m}$. The climate is of type Csa, which represents mesothermal climate, sub humid, with hot dry season and dry season (4-5 months) and rainy autumn to winter as the climatic classification of Köppen, adapted to Brazil (COELHO; SONCIN, 1982).

We adopted the randomized block design and treatments were arranged in a factorial $5 \times 2$, the first factor was hydric reposition (HR) of water consumption of the plant with wastewater $(0.25$; $0.50 ; 0.75 ; 1.00$ and 1.25 times of water consumed by the plant) and the second factor, the doses $\mathrm{P}_{2} \mathrm{O}_{5}$ (135 and 200 g plant $^{-1}$ year $^{-1}$ ) with four replications. The reference treatments were the irrigation $100 \%$ and the dose of $135 \mathrm{~g} \mathrm{plant}^{-1}$ (TOMINAGA et al., 2007). The wastewater stream is original Bodocongó, which serves as wastewater stream the open sky and presented in mean; $\mathrm{pH}, 7.5$, EC 1.3 $\mathrm{dS} \mathrm{m}{ }^{-1}, \mathrm{P}, \mathrm{K}$, total $\mathrm{N}, \mathrm{Ca}$ and $\mathrm{Mg}$, respectively, 6.7, 31.8, 59.7, 42.9 and $41.2 \mathrm{mg} \mathrm{L}^{-1}$ after treated in a UASB (upflow anaerobic sludge blanket).

The search was initiated in April 2007 at a spacing of $1.6 \times 1.7 \mathrm{~m}$. We used plastic containers with capacity of $200 \mathrm{~L}$ and one plant per pot. The soil was classified as Ultisol grayish eutrophic (SANTOS et al., 2006), sandy loam texture, without high contents of salinity and sodicity withdrawn of a layer 0-30 cm on the district of São José of Mata in Campina Grande, Paraiba, Brazil.

It should be noted that this work is a continuation of previous experiments conducted for two years. During this experiment we followed the fertilizer recommendations suggested by Novais, Neves and Barros (1991) from trials conducted in greenhouses. The soil was fertilized in the foundation with 100 , 300 and $150 \mathrm{mg} \mathrm{kg}^{-1}$ soil of $\mathrm{N}, \mathrm{P}_{2} \mathrm{O}_{5}$ and $\mathrm{K}_{2} \mathrm{O}$, using as source of nutrients, urea, superphosphate and potassium chloride, respectively, and for the second year followed the same recommendation for topdressing. 
At the beginning of the year third of production was made a drastic pruning, leaving all plants with height of $60 \mathrm{~cm}$. In the mineral fertilization were added $80 \mathrm{~g}$ of $\mathrm{N}, 62 \mathrm{~g}$ of $\mathrm{K}_{2} \mathrm{O}$ and two doses of $\mathrm{P}_{2} \mathrm{O}_{5}$ (135 and $200 \mathrm{~g}$ ). The fertilizers were applied fractionated and applied monthly during 12 months using the same sources of minerals.

The irrigations were performed in the end of afternoon in following irrigation schedule of three days, calculating the volume of water to be applied to the depth of irrigation of $1.00 \mathrm{HR}$ based on water balance (applied quantity - drained quantity) in the previous irrigation plus a fraction of leaching of 0.05 to ensure drainage of water and a fraction of confirmation that the ground has reached the ability of treatment field. During the experiment we performed the following cultural practices: manual removal of weeds, scarifying the soil surface every two irrigations and applications made once a week with products suitable for preventive control of diseases and pests.

To obtain data of stomatal conductance, transpiration, photosynthesis and leaf temperature, we used a portable measuring apparatus gas exchange (IRGA, mod. LCi System ADC, Hoddesdon, UK), in the expanded fourth leaf from the apex of the plant. However, this practice was only carried out on plants of physic nut receiving the lowest dose of phosphorus $\left(\mathrm{PD}_{1}: 135 \mathrm{~g}\right)$, since it, in preliminary analysis there was no difference in the readings of gas exchange, between the two doses $\left(\mathrm{PD}_{1}\right.$ and $\left.\mathrm{PD}_{2}\right) \mathrm{P}_{2} \mathrm{O}_{5}$. Measurements were performed under saturating light, using an artificial source of radiation and in ambient condition of temperature and concentration of $\mathrm{CO}_{2}$. The readings were performed in the inflorescence period, which corresponds to the highest concentration of nutrients in the plant and photosynthetic activity.

To quantify the contents of macro and micronutrients and sodium, we selected mature leaves, healthy and without attack of pest and diseases, located between the fourth and leaf fifth below the inflorescence. The plant material was washed with distilled water and dried in oven forced air at $60{ }^{\circ} \mathrm{C}$ to constant weight. After drying, the samples were weighed, grinded and submitted to chemical analysis according to the methods recommended by Silva (1999).

The data were evaluated by analysis of variance by $F$ test at the 0.05 level of probability and in cases of significance, analysis was performed for linear and quadratic polynomial regression using statistical software SISVAR-ESAL (FERREIRA, 2003).

\section{Results and Discussion}

It is observed that the results did not affect the hydric reposition of water consumption with wastewater for stomatal conductance, transpiration rate and leaf temperature in leaves of physic nut (Table 1). However, for the variable rate of photosynthesis was no significant effect.

Table 1. Summary of analysis of variance for stomatal conductance (gs), transpiration rate (E), rate of photosynthesis (A) and leaf temperature (T) in physic nut irrigated with wastewater with differents reposition hydric during the third year of production in the period flowering.

\begin{tabular}{|c|c|c|c|c|c|}
\hline \multirow{2}{*}{ Cause of Variation } & & \multicolumn{4}{|c|}{ Average Squares } \\
\hline & & gs & $\mathrm{E}$ & A & $\mathrm{T}$ \\
\hline Hydric Reposition (HR) & 4 & $0.003 \mathrm{~ns}$ & $0.48 \mathrm{~ns}$ & $115.59 * *$ & $0.46 \mathrm{~ns}$ \\
\hline Block & 3 & $0.0003 \mathrm{~ns}$ & $0.51 \mathrm{~ns}$ & $2.40 \mathrm{~ns}$ & $1.55 \mathrm{~ns}$ \\
\hline Residue & 12 & 0.0003 & 0.33 & 2.71 & 0.35 \\
\hline CV $(\%)$ & & 83.77 & 74.03 & 14.79 & 1.75 \\
\hline
\end{tabular}

** significant $(\mathrm{p}<0.01)$ e ns - no significativo $(\mathrm{p}>0.05)$ by $\mathrm{F}$ test.

Source: Elaboration of the authors. 
The stomatal conductance measured in the leaves of physic nut ranged from 0.035 to $0.060 \mathrm{mmol} \mathrm{m}^{-2}$ $\mathrm{s}^{-1}$ respectively, between the extremes of HR (hydric reposition) treatments, but the differences were not statistically significant. ToAtteya (2003) the reduction in stomatal conductance in plants subjected to water stress are associated with the decline in water potential and the relative water content in the leaf. The stomatal conductance values obtained in this study are considered low when compared to those reported by other authors, which can be explained, at least in part, by the accumulation of salts in the soil caused by the application of wastewater that had electrical conductivity of $1.39 \mathrm{dS} \mathrm{m}^{-1}$, including the first two growing years that preceded this study. This fact confirmed was by Sousa et al. (2011) who claim that physic nut demonstrates sensitivity to salinity of irrigation water with electrical conductivity higher than $1.6 \mathrm{dS} \mathrm{m}^{-1}$.
The transpiration rate varied between treatments 0.50 and $0.73 \mathrm{mmol} \mathrm{m}^{-2} \mathrm{~s}^{-1}$. In general the data rate of transpiration obtained in this study are well below those found by Santos (2008) who studied gas exchange in physic nut grown under rainfed conditions, where obtained in the wet and dry season transpiration was 1 and $4 \mathrm{mmol} \mathrm{m}^{-2} \mathrm{~s}^{-1}$, respectively. The low values are consistent with the low values of stomatal conductance, as discussed in the previous paragraph.

The rates of photosynthesis were affected significantly (Figure 1) from water depths and the values obtained ranged from 4.41 the 17.83 mmol m-2 $\mathrm{s}^{-1}$ between the treatments of HR 0.25 to 1.25 respectively. In addition to water availability growing that favors plants better condition, the use of wastewater for irrigation improves physiological performance probably in large part on the availability of plant nutrients especially nitrogen present in wastewater of domestic origin (SOUZA et al., 2010).

Figure 1. Rate of photosynthesis - A, in physic nut irrigated with wastewater with different reposition hydric during the third year of production in the period of flowering

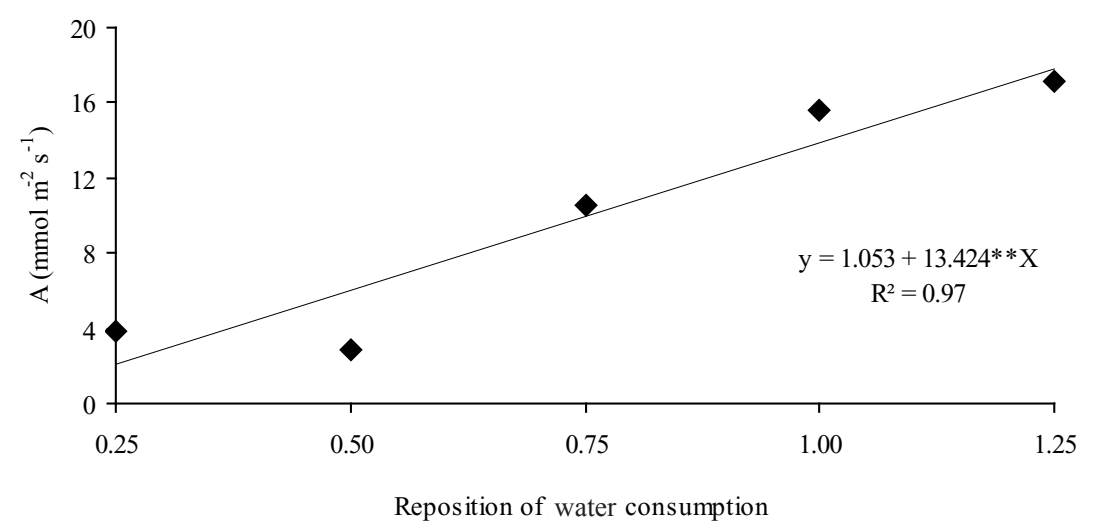

Source: Elaboration of the authors. 
According with Maggiotto (1996), in addition of solar radiation, the leaf temperature is associated to parameters, such as low water content in the soil, or simply the discrepancy between in relationship water absorption in the perspiration of the crop. However the temperature variation of leaf physic nut observed between the depth of water was small (2.63\%) ranging from 33.28 the $34.18{ }^{\circ} \mathrm{C}$, between depth HR of 1.25 and 0.75 . The transpiration is the main mechanism involved in the regulation of leaf temperature, the smaller opening of the stomata, higher the temperature leaf (MACHADO et al., 2005).
It is observed in Table 2, analyzes of variance for the content of nitrogen, phosphorus, potassium, calcium, magnesium and sulfur. Observed to have occurred a significant effect of hydric reposition $(\mathrm{p}<0.01)$, per the $\mathrm{F}$ test on the content of phosphorus, calcium and magnesium. On dose factor of phosphorus (PD) was not significant effect. However, there was observed interaction significant ( $p<0.01)$ among the factors for calcium and magnesium, indicating that the hydric reposition affects the amount of calcium and magnesium together with the phosphorus or vice versa.

Table 2. Summary of analysis of variance for levels of nitrogen $(\mathrm{N})$, phosphorus $(\mathrm{P})$, potassium $(\mathrm{K})$, calcium $(\mathrm{Ca})$, magnesium $(\mathrm{Mg})$ and sulfur $(\mathrm{S})$ in the leaf of physic nut irrigated with wastewater with differents reposition hydric during the third year of production in the period of flowering.

\begin{tabular}{lccccccc}
\hline \multirow{2}{*}{\multicolumn{1}{c}{ Cause of Variation }} & & \multicolumn{7}{c}{ Average Squares } \\
\cline { 3 - 8 } & & $\mathrm{N}$ & $\mathrm{P}$ & $\mathrm{K}$ & $\mathrm{Ca}$ & $\mathrm{Mg}$ & $\mathrm{S}$ \\
Hydric Reposition (HR) & 4 & $16.15 \mathrm{~ns}$ & $3.42^{* *}$ & $74.38 \mathrm{~ns}$ & $390.78^{* *}$ & $3.65^{* *}$ & $0.010 \mathrm{~ns}$ \\
Linear Regression & 1 & - & $9.52^{* *}$ & - & $352.84^{* *}$ & $7.33^{* *}$ & - \\
Quadratic Regression & 1 & - & $3.99^{* *}$ & - & $725.07^{* *}$ & $1.51^{* *}$ & - \\
Regression Deviation & 2 & - & $0.09 \mathrm{~ns}$ & - & $242.60^{* *}$ & $2.87^{* *}$ & - \\
Phosphorus Dose (PD) & 1 & $0.84 \mathrm{~ns}$ & $1.87 \mathrm{~ns}$ & $3.75 \mathrm{~ns}$ & $23.69 \mathrm{~ns}$ & $0.24 \mathrm{~ns}$ & $0.004 \mathrm{~ns}$ \\
Interaction HR x PD & 4 & $12.56 \mathrm{~ns}$ & $0.33 \mathrm{~ns}$ & $10.42 \mathrm{~ns}$ & $216.79^{* *}$ & $3.80^{* *}$ & $0.03 \mathrm{~ns}$ \\
\hline Block & 3 & $9.28 \mathrm{~ns}$ & $0.22 \mathrm{~ns}$ & $22.39 \mathrm{~ns}$ & $4.58 \mathrm{~ns}$ & $0.30 \mathrm{~ns}$ & $0.02 \mathrm{~ns}$ \\
Residue & 27 & 12.60 & 0.51 & 34.44 & 13.68 & 0.29 & 0.02 \\
CV $(\%)$ & & 10.48 & 15.01 & 18.03 & 14.15 & 8.17 & 33.03 \\
\hline
\end{tabular}

** significant $(\mathrm{p}<0.01)$ e ns - no significativo $(\mathrm{p}>0.05)$ by $\mathrm{F}$ test.

Source: Elaboration of the authors.

According the regression studies, the increase in hydric reposition for the plants showed a quadratic correlation for content of phosphorus in plant leaves (Figure 2). It is observed according to the regression equation, which in the hydric reposition of 0.50 , $0.75,1.00$ and $1.25(\mathrm{HR})$ there was an increase in phosphorus content of $24.77,39.29,43.53$ and $37.52 \%$ compared to the HR of 0.25 , respectively, so based on these results it is observed that there was a greater concentration of phosphorus $(5.28 \mathrm{~g}$ $\mathrm{kg}^{-1}$ ) when reset the water requirement of 0.98 of water need of the crop. 
Figure 2. Content of phosphorus in the leaf $-\mathrm{P}$, of physic nut irrigated with wastewater with different reposition hydric during the third year of production in the period of flowering.

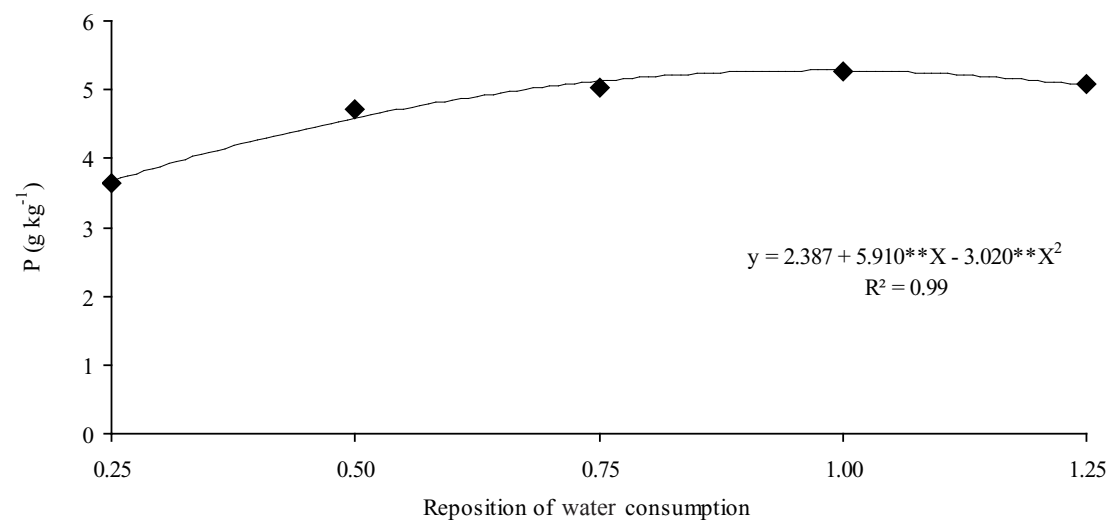

Source: Elaboration of the authors.

Phosphorus and the potassium are elements that require moisture for their distribution and the increased hydric reposition resulted in higher content of soil moisture, hence solubility and higher greater concentration in soil solution providing increased availability of these nutrient for plants, for Furthermore the wastewater of urban origin used for irrigation had $6.7 \mathrm{mg} \mathrm{L}^{-1}$ of phosphorus, which implies an extra contribution of nutrients in the soil compared to the water supply sources what not normally has presenting any content of phosphorus in chemical analysis.
Similar result observed for phosphorus was recorded for the calcium content, with the depth of water of $0.50,0.75$ and 1.00, showing an increase in calcium content of $21.91,23.66$ and $5.27 \%$ in relation to the depth of 0.25 respectively, but when comparing the depth of 0.25 with the depth of 1.25 is noted a decrease of $33.26 \%$. It was also observed that the maximum content of calcium in the plant leaves was obtained with a depth of 0.65 (HR) with $31.67 \mathrm{~g} \mathrm{~kg}^{-1}$ (Figure 3A).

Figure 3. Content of calcium - Ca (A) and magnesium - Mg (B) in the leaf of physic nut irrigated with wastewater with different reposition hydric during the third year of production in the period of flowering.
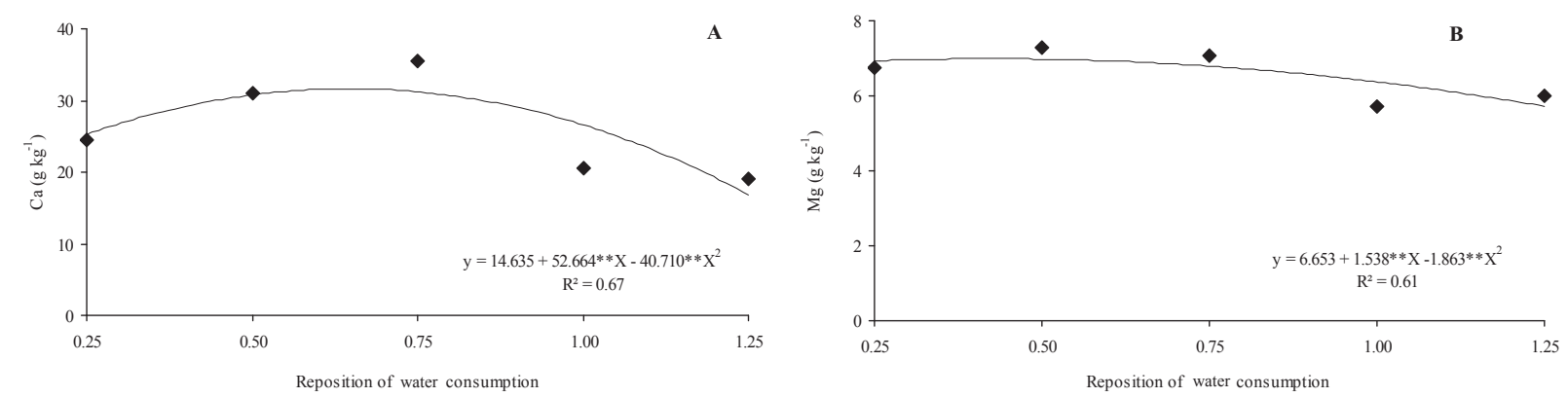

Source: Elaboration of the authors. 
The wastewater used for irrigation contained an average concentration of 156.1, 31.8 and 59.7 $\mathrm{mg} \mathrm{L}^{-1}$ of sodium, potassium and total nitrogen, respectively. The increased of HR resulted in more elements available at the solution of soil possibly affecting the absorption of calcium, which explains the lower values for larger depth of HR. Addition to the transpiration, the concentration of ions in the external solution, mainly sodium, and the presence antagonistic of ions (potassium and ammonium) reduce the absorption of calcium (MARENCO; LOPES, 2005).

Physic nut is demanding in calcium, it is important that the soil presents adequate content of this nutrient to not limit its growth and production (LAVIOLA; DIAS, 2008). In general, it is ideal that the calcium content in the soil is maintained in the proper range, above $3.5 \mathrm{dm}^{3} \mathrm{cmol}_{\mathrm{c}}$ considering a ratio of 4 to 3:1 with magnesium (ALVAREZ et al., 1999).

Regarding the magnesium content, it turns out that the negative effect provoked by the increased hydric reposition, follows quadratic model ( $p$ $<0.01$ ), obtaining a difference between the lowest $17.48 \% \mathrm{HR}(0.25)$ and highest (1.25), and the points of maximum and minimum achieved were 6.98 and $5.72 \mathrm{~g} \mathrm{~kg}^{-1}$ for HR 0.50 and 1.25 , respectively, however, the higher content of magnesium was obtained with a HR 0.42 of according to the equation (Figure 3B). It is observed that the water deficit enhanced the magnesium concentration in the leaves of the plant, which due to the fact that magnesium is an element easily translocated from older tissues to younger and growth active. Magnesium is responsible for maintaining balanced
$\mathrm{pH}$, the balance loads cytosol and the of chloroplast stroma, addition to its function in protein synthesis (MARSCHNER, 1995). Thus, significant reductions in contents of magnesium can cause malfunction of chloroplasts directly affecting photosynthesis and plant development.

The physic nut has a high content of nutrients in the leaves, with the following order of accumulation: $\mathrm{N}>\mathrm{K}>\mathrm{Ca}>\mathrm{Mg}>\mathrm{P}>\mathrm{S}$. It is a plant that has a high growth rate, and the nitrogen is essential for the assimilation of carbon and formation of new organs in the plant (TAIZ; ZEIGER, 2004). The nitrogen/ potassium relationship was 1.4 in the leaves and these nutrients are required in the activation of various enzymes essential to the synthesis of organic compounds, including starch (MARENCO; LOPES, 2005).

The analyzes of variance and the averages observed for the levels of iron, zinc, chloride, copper, manganese and sodium in the leaves of physic nut, are summarized in Table 3. It's verified that there was no significant effect of hydric reposition only for the iron content. In regarding the dose of phosphorus and the interaction of factors, no significant difference in any of the elements evaluated.

The increase of hydric reposition results in a linear increase in the zinc content of the leaves (Figure 4A), occurring increments in relation to 0.25 HR according to the mathematical models of 14.04 , $28.08,42.12$ and $56.15 \%$, the hydric reposition of $0.50,0.75,1.00$ and 1.25 , respectively, representing increases of $14.04 \%$ for each increase of 0.25 in the HR. 
Table 3. Summary of analysis of variance for levels of iron (Fe), zinc $(\mathrm{Zn})$, copper $(\mathrm{Cu})$, manganese $(\mathrm{Mn})$, chlorine $(\mathrm{Cl})$ and sodium $(\mathrm{Na})$ in the leaf of physic nut irrigated with wastewater with differents reposition hydric during the third year of production in the period of flowering.

\begin{tabular}{|c|c|c|c|c|c|c|c|}
\hline \multirow{2}{*}{ Cause of Variation } & & \multicolumn{6}{|c|}{ Average Squares } \\
\hline & & $\mathrm{Fe}$ & $\mathrm{Zn}$ & $\mathrm{Cu}$ & $\mathrm{Mn}$ & $\mathrm{Cl}$ & $\mathrm{Na}$ \\
\hline Hydric Reposition (HR) & 4 & $1107.18 \mathrm{~ns}$ & $356.63 * *$ & $7.27 * *$ & $3908.68 * *$ & $912.47 * *$ & $193109299.36^{* *}$ \\
\hline Linear Regression & 1 & - & $847.34 * *$ & $20.51 * *$ & $21376.32 * *$ & $2498.95 * *$ & $724246803.87^{* *}$ \\
\hline Quadratic Regression & 1 & - & $20.61 \mathrm{~ns}$ & $7.87 * *$ & $4412.71 \mathrm{~ns}$ & $413.49 * *$ & $46583500.28^{* *}$ \\
\hline Regression Deviation & 2 & - & $279.29 * *$ & $0.34 \mathrm{~ns}$ & $19.25 \mathrm{~ns}$ & $13.12 \mathrm{~ns}$ & $803446.64 \mathrm{~ns}$ \\
\hline Phosphorus Dose (PD) & 1 & $96.63 \mathrm{~ns}$ & $7.98 \mathrm{~ns}$ & $0.54 \mathrm{~ns}$ & $2360.99 \mathrm{~ns}$ & $5.46 \mathrm{~ns}$ & $4075622.21 \mathrm{~ns}$ \\
\hline Interaction HR x PD & 4 & $411.91 \mathrm{~ns}$ & $34.52 \mathrm{~ns}$ & $0.72 \mathrm{~ns}$ & $98.17 \mathrm{~ns}$ & $45.47 \mathrm{~ns}$ & $11477914.18 \mathrm{~ns}$ \\
\hline Block & 3 & $603.56 \mathrm{~ns}$ & $94.63 \mathrm{~ns}$ & $0.733 n s$ & $344.91 \mathrm{~ns}$ & $2.07 \mathrm{~ns}$ & $1337745.10 \mathrm{~ns}$ \\
\hline Resídue & 27 & 544.46 & 32.98 & 0.34 & 804.03 & 20.91 & 6387747.48 \\
\hline CV (\%) & & 21.46 & 19.34 & 12.60 & 36.62 & 32.66 & 23.05 \\
\hline
\end{tabular}

** significant $(\mathrm{p}<0.01)$ e ns - no significativo $(\mathrm{p}>0.05)$ by $\mathrm{F}$ test.

Source: Elaboration of the authors.

Figure 4. Content of zinc - Zn (A) and copper - Cu (B) in the leaf of physic nut irrigated with wastewater with different reposition hydric during the third year of production in the period of flowering

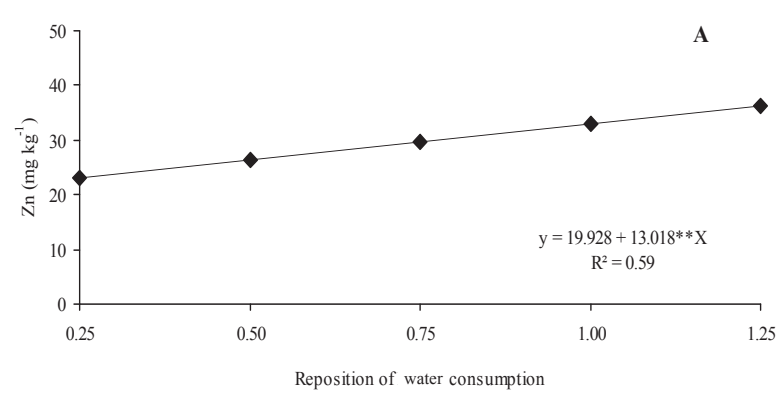

Source: Elaboration of the authors.

To the copper content was observed effect linear to the hydric reposition factor (Figure 4B) and according the regression studies, obtained there a difference of approximately $56 \%$ increase between 0.25 and $1.25 \mathrm{HR}$, with the points, maximum and minimum of $5.60 \mathrm{mg} \mathrm{kg}^{-1}(1.25 \mathrm{HR})$ and $3.58 \mathrm{mg}$ $\mathrm{kg}^{-1}$ (0.52 HR), respectively. It is proven through the above results which showed higher copper concentration in the leaves of physic nut. As zinc and copper are present in the wastewater, with the increase in HR demonstrated increased levels of these elements in the leaves.

The increase of hydric reposition inhibited linearly the manganese content (Figure 5). It is

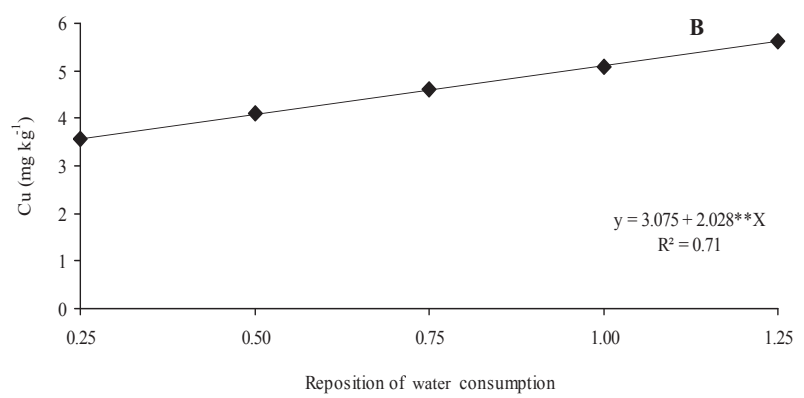

observed in regression equations that there was a reduction in the concentration of the nutrient from the HR 0.25 , and that, $1.25 \mathrm{HR}$ decreased by $57.68 \%$, corresponding to the reduction of $14.42 \%$, by increased of 0.25 in the HR.

According to the studies of regression (Figure $6 \mathrm{~A}$ ), increased reposition of irrigation in the plants resulted in a decrease in chlorine content linearly, according to the regression model found, with an estimated $90.7 \%$ difference between the hydric reposition of 0.25 and 1.25 , between the ranges of reposition evaluated, with the points of maximum and minimum of 24.65 and $2.29 \mathrm{mg} \mathrm{kg}^{-1}$, respectively. 
Figure 5. Content of manganese - Mn, in the leaf of physic nut irrigated with wastewater with different reposition hydric during the third year of production in the period of flowering

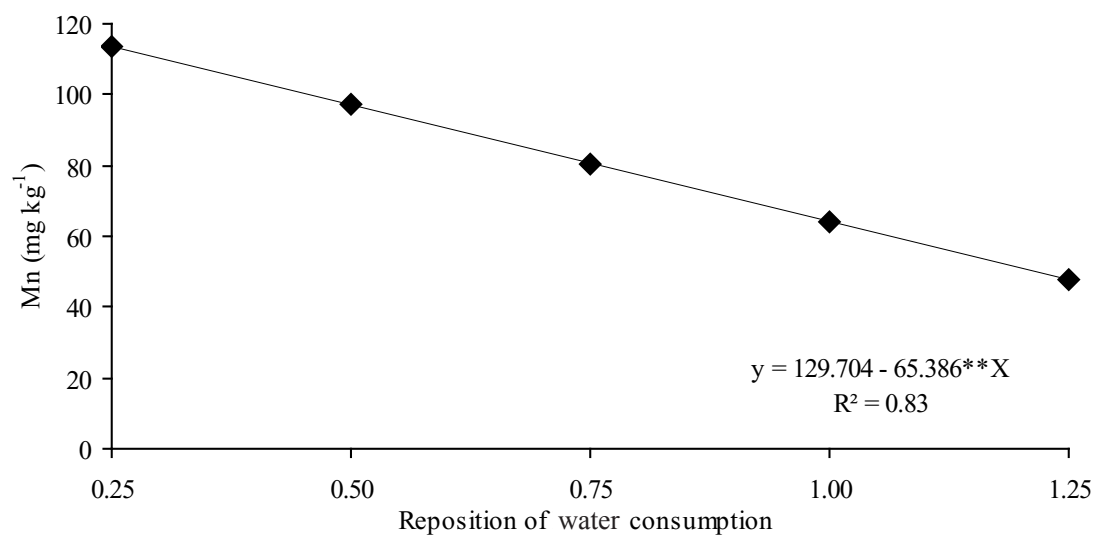

Source: Elaboration of the authors.

The increase of hydric reposition resulted in a decrease in sodium content in the leaves of physic nut (Figure 6B), occurring decrease, according to the mathematical models used of $17.72 \%$, for each increment of the interval evaluated (HR 0.25 ), thus verifying that there has been an approximately $71 \%$ difference between the lowest (0.25) and bigger hydric reposition (1.25). The levels of sodium and manganese declined in leaves physic nut that received more water possibly by plant height (biomass quantity) and by this the manganese and sodium must have been diluted in the physiological structure.

Figure 6. Content of chlorine $-\mathrm{Cl}(\mathrm{A})$ and sodium $-\mathrm{Na}(\mathrm{B})$ in the leaf of physic nut irrigated with wastewater with different reposition hydric during the third year of production in the period of flowering.

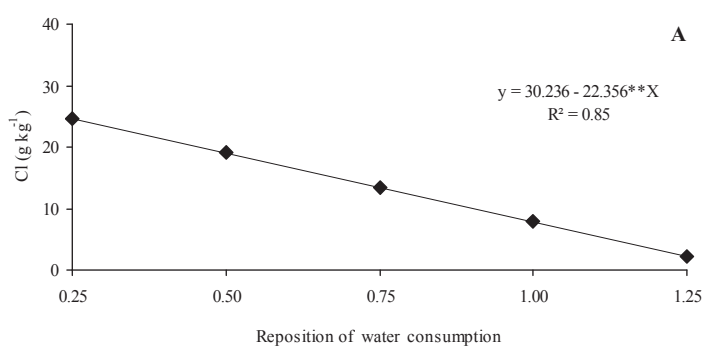

Source: Elaboration of the authors.

The order of accumulation of sodium and micronutrients obtained for the leaves of physic nut was as follows: $\mathrm{Na}>\mathrm{Cl}>\mathrm{Fe}>\mathrm{Mn}>\mathrm{Zn}>\mathrm{Cu}$. The fact of sodium and chloride be the first elements in order of accumulation in the leaves is justified by

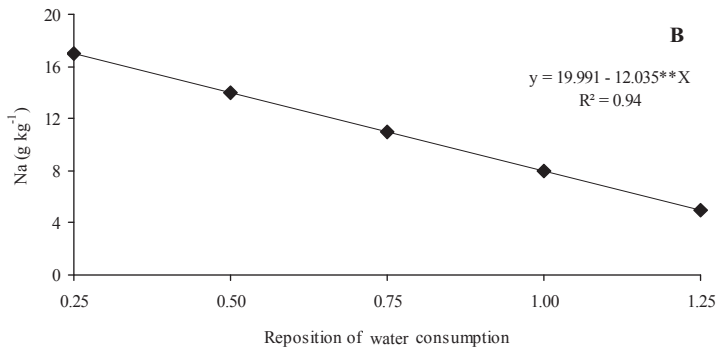

the high electrical conductivity of the wastewater in the order of $1.39 \mathrm{dS} \mathrm{m}^{-1}$. The high content of sodium and chloride is associated with its availability in the soil, resulting from application of wastewater for irrigation. 


\section{Conclusions}

The increase of hydric reposition with wastewater, provided an increase of leaf gas exchange especially in the rate of carbon assimilation.

The content of elements follows in the order in descending in the leaves: $\mathrm{N}>\mathrm{K}>\mathrm{Ca}>\mathrm{Na}>\mathrm{Cl}>$ $\mathrm{Mg}>\mathrm{P}>\mathrm{S}>\mathrm{Fe}>\mathrm{Mn}>\mathrm{Zn}>\mathrm{Cu}$.

With increasing of hydric reposition the contents in the leaf of elements phosphorus, zinc and copper increased while the levels of chlorine, manganese, sodium decreased their concentrations in the leaves.

The phosphorus rates applied did not influence the levels of any of the elements studied.

\section{Acknowledgement}

The Conselho Nacional de Pesquisa e Desenvolvimento Cientifico e Tecnológico-CNPq, by granting financial support and scholarship, to the first author and by realization this work.

\section{References}

ALVAREZ, V. V. H.; NOVAIS, R. F.; BARROS, N. F.; CATARUTTI, R. B.; LOPES, A. S. Interpretação dos resultados das análises de solos. In: RIBEIRO, A. C.; GUIMARÃES, P. T. G.; ALVAREZ, V. V. H. Ed.). Recomendações para o uso de corretivos e fertilizantes em Minas Gerais. Viçosa: Comissão de Fertilidade do Solo do Estado de Minas Gerais, 1999. p. 25-32.

ATTEYA, A. M. Alteration of water relations and yield of corn genotypes in response to drought stress. Bulgarian Journal of Plant Physiology, Sofia, v. 29, n. 3, p. 63-76, 2003.

AZEVEDO, M. R. de Q. A.; KONIG, A; BELTRÃO, N. E. de M.; AZEVEDO, C. A. V. de; TAVARES, T. de L.; SOARES, F. A. L. Efeito da irrigação com água residuária tratada sobre a produção de milho forrageiro. Revista Brasileira Ciência Agrária, Recife, v. 2, n. 1, p. 63-64, 2007.

BELTRÃO, N. E. de M. Agronegócio das oleaginosas no Brasil. Informe Agropecuário, Belo Horizonte, v. 26, n. 229, p. 44-78, 2005.
BELTRÃO, N. E. de M.; SOUZA, J. G. de; SANTOS, J. W. dos; JERÔNIMO, J. F.; COSTA, F. X.; LUCENA, A. M. de A.; FERREIRA, U. C. de Q. Fisiologia da mamoneira, cultivar BRS 149 nordestina, na fase inicial de crescimento, submetida a estresse hídrico. Revista Brasileira de Oleaginosas e Fibrosa, Campina Grande, v. 7, n. 1, p. 659-664, 2003.

BLUM, J. R. C. Critérios e padrões de qualidade de água. In: MANCUSO, P. C. S.; SANTOS, H. F. dos. (Ed.). Reúso de água. São Paulo: USP, 2003, p. 125-174.

CAPRA, A.; SCICOLONE, B. Recycling of poor quality urban wastewater by drip irrigation systems. Journal of Cleaner Production, Knoxville, v. 5, n. 4, p. 1529-1534, 2007.

COELHO, M. A.; SONCIN, N. B. Geografia do Brasil. São Paulo: Moderna, 1982. 368 p.

DENG, X.; HU, Z. A.; WANG, H. X.; WEN, X. G.; KUANG, T. Y. A comparison of photosynthetic apparatus of the detached leaves of the resurrection plant Boea hygrometrica with its con-tolerant relative Chirita hererotrichia in response to dehydration and rehydration. Plant Science, Davis, v. 165, n. 4, p. 851-861, 2003.

ERISMANN, N. M.; MACHADO, E. C.; GODOY, I. J. Capacidade fotossintética de genótipos de amendoim em ambiente natural e controlado. Pesquisa Agropecuária Brasileira, Brasília, v. 41, n. 7, p. 1099-1108, 2006.

FERREIRA, D. F. SISVAR 4.6 sistema de análises estatísticas. Lavras: UFLA, 2003. 32 p.

FERREIRA, O. E.; BELTRÃO, N. E. de M.; KONIG, A. Efeitos da aplicação de água residuária e nitrogênio sobre o crescimento e produção do algodão herbáceo. Revista Brasileira de Oleaginosas e Fibrosas, Campina Grande, v. 9, n. 1, p. 893-902, 2005.

HERPIN, V.; GLOAGUEN, T. V.; FONSECA, A. F. da; MONTES, C. R.; MENDONÇA, F. C.; PIVELI, R. P.; BREULMANN, G.; FORTI, M. C.; MELFI, A. J. Chemical effects on the soil-plant system in a secondary treated wastewater irrigated coffee plantation - a pilot field study in Brazil. Agricultural Water Management, Amsterdam, v. 89, n. 1, p. 105-115, 2007.

JOHNS, G. G.; MCCONCHIE, D. M. Irrigation of bananas with secondary treated sewage effluent II. Effect of plant nutrients, additional elements and pesticide residue in plants, soil and leachate using drainage lysimeters. Australian Journal of Agricultural Research, Victoria, v. 45, n. 1, p. 1601-1617, 1994.

LARCHER, W. Ecofisiologia vegetal. São Carlos: Rima Artes, 2004. 531 p. 
LAVIOLA, B. G.; DIAS, L. A. dos S. Teor e acúmulo de nutrientes em folhas e frutos de pinhão manso. Revista Brasileira de Ciência do Solo, Viçosa, v. 32, n. 5, p. 1969-1975, 2008.

LAVIOLA, B. G.; MARTINEZ, H. E. P.; SOUZA, R. B.; SALOMÃO, L. C. C.; CRUZ, C. D. Acúmulo de macronutrientes em frutos de cafeeiros em ViçosaMG. In: SIMPÓSIO DE PESQUISA DOS CAFÉS DO BRASIL, 5., 2007, Águas de Lindóia. Anais... EMBRAPA, Águas de Lindóia, 2007. CD-ROM.

LEMOS-FILHO, J. R. Fotoinibição em três espécies do cerrado (Annona crassifolia, Eugenia dysenterica e Campomanesia adamantium) na estação seca e na chuvosa. Revista Brasileira de Botânica, São Paulo, v. 23, n. 1, p. 45-50, 2000.

LUCENA, A. M. A. de; GUERRA, H. O. C.; CHAVES, L. H. G.; COSTA, F. X. Influência da natureza do substrato e da água de irrigação no crescimento de mudas de flamboyant (Delonix regia). Revista Caatinga, Mossoró, v. 20, n. 3, p. 112-120, 2007.

MACEDO, F. L. de; PEDRA, W. N.; SILVA, S. A.; BARRETO, M. C. de V.; SILVA-MANN, R. Efeito do alumínio em plantas de Pinhão Manso (Jatropha curcas L.), cultivadas em solução nutritiva. Semina: Ciências Agrárias, Londrina, v. 32, n. 1, p. 157-164, 2011.

MACHADO, E. C.; SCHMIDT, P. T.; MEDINA, C. L.; RIBEIRO, R. V. Respostas da fotossíntese de três espécies de citros a fatores ambientais. Pesquisa Agropecuária Brasileira, Brasília, v. 40, n. 12, p. 1161-1170, 2005.

MAGGIOTTO, S. R. Estimativa da evapotranspiração de referência pelo uso da termometria ao infravermelho. 1996. Dissertação (Mestrado em Irrigação e Drenagem) - Universidade de São Paulo, Piracicaba.

MARENCO, R. A.; LOPES, N. F. Fisiologia vegetal: fotossíntese, respiração, relações hídricas e nutrição mineral. Viçosa: UFV, 2005. 451 p.

MARSCHNER, H. Mineral nutrition of higher plants. San Diego: Academic Press, 1995. 889 p.

MEDEIROS, S. S.; SOARES, F. A. L.; GHEYI, H. R.; FERNANDES, P. D. Uso de água residuária de origem urbana no cultivo de gérberas: efeito nos componentes de produção. Engenharia Agrícola, Jaboticabal, v. 27, n. 2, p. 569-578, 2007.

NOBRE, R. G.; GHEYI, H. R.; ANDRADE, L. O. de; SOARES, F. A. L.; NASCIMENTO, E. C. S. Crescimento do girassol irrigado com água residuária e adubação orgânica. Revista DAE, São Paulo, v. 4, n. 1, p. 50-60, 2009.
NOGUEIRA, R. J. M. C.; SANTOS, R. C. Alterações fisiológicas no amendoim submetido ao estresse hídrico. Revista Brasileira de Engenharia Agrícola Ambiental, Campina Grande, v. 4, n. 1, p. 41-45, 2000.

NOVAIS, R. F.; NEVES, J. C. L.; BARROS, N. F. Ensaios em ambiente controlado. In OLIVEIRA, A. J.; GARRIDO, W. E.; ARAUJO, J. D.; LOURENÇO, S. Métodos de pesquisa em fertilidade de solo. Brasília: Embrapa Informação e Tecnologia, 1991. p. 189-253.

REBOUÇAS, J. R. L.; DIAS, N. da S.; GONZAGA, M. I. da S.; GHEYI, H. R.; SOUZA NETO, O. N. de. Crescimento do feijão-caupi irrigado com água residuária de esgoto doméstico tratado, Revista Caatinga, Mossoró, v. 23, n. 1, p. 97-102, 2010.

SANTOS, C. M. dos. Fenologia e capacidade fotossintética do pinhão manso (Jatropha curcas L.) em diferentes épocas do ano no estado de Alagoas. 2008. Dissertação (Mestrado em Agronomia) - Universidade Federal de Alagoas, Rio Largo.

SANTOS, H. G. dos; JACOMINE, P. K. T.; ANJOS, L. H. C. dos; OLIVEIRA, V. A. de; OLIVEIRA, J. B. de; COELHO, M. R.; LUMBRERAS, J. F.; CUNHA, T. J. F. (Ed.). Sistema brasileiro de classificação de solos. 2. ed. Rio de Janeiro: Embrapa Solos, 2006. 306 p.

SILVA, F. C. Manual de análises químicas de solo, plantas e fertilizantes. Brasília: Embrapa Informação e Tecnologia, 1999, $370 \mathrm{p}$.

SOUSA, A. E. C.; GHEYI, H. R.; CORREIA, K. G.; SOARES, F. A. L.; NOBRE, R. G. Crescimento e consumo hídrico de pinhão manso sob estresse salino e doses de fósforo. Revista Ciência Agronômica, Fortaleza, v. 42, n. 2, p. 310-318, 2011.

SOUSA, J. T.; CEBALLOS, B. S. O.; HENRIQUE, I. N.; DANTAS, J. P.; LIMA, S. M. S. Reúso de água residuária na produção de pimentão (Capsicum annuum L.). Revista Brasileira de Engenharia Agricola e Ambiental, Campina Grande, v. 10, n. 1, p. 89-96, 2006.

SOUZA, R. M. de; NOBRE, R. G.; GHEYI, H. R.; DIAS, N. da S.; SOARES, F. A. L. Utilização de água residuária e de adubação orgânica no cultivo do girassol. Revista Caatinga, Mossoró, v. 23, n. 2, p. 125-133, 2010.

TAIZ, L.; ZEIGER, E. Fisiologia vegetal. 3. ed. Porto Alegre: Artmed, 2004. 719 p.

TOMINAGA, N.; KAKIDA, J.; YASUDA, E. K.; SOUSA, L. A. S.; RESENDE, P. L.; SILVA, N. D. Cultivo de pinhão manso para produção de biodiesel. Viçosa: CPT, 2007. 220 p. 
van der HOEK, W.; HASSAN, U. M.; ENSINK, J. H. J.; FEENSTRA, S.; RASCHID-SALLY, L.; MUNIR, S.; ASLAM, R.; ALIM, N.; HUSSAIN, R.; MATSUNO, Y. Urban wastewater: a valuable resource for agriculture. A case study from Horoonabad. Pakistan. Colombo, Sri Lanka: International Water Management Institute, 2002. 29 p. (Research Report, 63).

WORLD HEALTH ORGANIZATION - WHO. Health guidelines for wastewater in agriculture and aquaculture. Technical Report Series, 778. Geneva: World Health Organization, 1989. $74 \mathrm{p}$. 
